\title{
Effect of Pumpkin (Cucurbita Sp.) Seeds and Husk Tomato (Tomatillo) on Obese Rats Suffering from Diabetes
}

\author{
Shimaa Mohammed Hasnin Aboelnaga \\ Preparatory Year, University of Hail, KSA
}

\begin{abstract}
Nowadays, diabetes represents one of the major metabolic ailment challenge in the human community. The aim of this study was to scrutinize effectsof pumpkin seeds, husk tomato and their combination on diabetic-obese rats. Forty eight male albino rats (Sprague DawleyStrain) were divided into two main groups. The first main group (n=6) rats were fed on a basal diet (control negative, $C$-). The second main group $(n=42)$ rats were fed on a high-fat diet $(H F D)$ for six weeks to induce obesity. The rats in the second group (obese group) were administered with alloxan (120mg alloxan $/ \mathrm{kg}$ bodyweight) to induce diabetes. Four days later, body weight gain was estimated for all rats in the first and second main groups and blood samples were collected from the eye ball of all rats to determinethelevelsofglucose, cholesterol and triglycerides. Thereafter,the second group rats were subdivided intosevensubgroups; subgroup 1(control positive, C+) animals fed on HFD, subgroup 2 (PS5) and 3(PS10) animals werefed on HFDcontaining 5and 10\%driedpumpkinseeds, respectively,subgroup 4 (HT5) and 5(HT10) animals were fed on HFD containing 5and 10\% husktomato, respectively andsubgroup 6 (PH3) and $7($ PH6) animals were fed on HFD containing 3\% pumpkinseeds+ 3\% husk tomato and 6\% pumpkinseeds $+6 \%$ husktomato, respectively. Therefore 8 groups were designed and treatment lasted for 42 days.Positive control(obesediabetic) rats exhibitedsignificant $(P<0.05)$ increase in body weightgain, relative organsweight, lipid profile except HDL, kidneyfunctions, liver enzymes, glucose and leptin ascompared to thenegative control rats. Supplementing obesediabeticratswithpumpkinseeds, husktomato or theircombination decreased $(P<0.05 \mid)$ body weightgain, relative liver and kidneyweights, serum cholesterol, triglycerides, LDL, VLDL, uric acid, urea nitrogen, creatinine, AST, ALT ALP, glucose and leptin, while HDL increased.Thebestimprovement was shown in rats given6\% pumpkinseeds $+6 \%$ husktomato. In conclusion, pumpkinseedand husktomatorevealed signs of improvement in obese-diabetic rats which might be a good approach to be applied in human suffering from diabetes complications.
\end{abstract}

Keywords: Pumpkin seeds, husk tomato, diabetes, obesity, rats, metabolic attributes, kidney function

\section{Introduction}

Diabetes is a common endocrine disorder, affecting more than 100 million people worldwide and the World Health Organization predicts this number will increase fivefold in the near future Although insulin is the most common conventional treatment for diabetes [1], diet therapy approaches have demonstrated many advantages in developing countries [1]; [16]. Obesity is one of the major risk factor for morbidity and mortality and has a strong association with diabetes. Obesity may be defined as abnormal growth of adipose tissue [35]. It has been recently known that using alternative complimentary medicine by several communities worldwide to get use of the natural contents in herbs, vegetables and fruits instead of using chemicals as medicine. Pumpkin seeds and oils have drawn the attention of many researchers around the world. It has been shown that pumpkin seed oils are beneficial as treatment of benign prostatic hyperplasia, enhancement of immunity, hypolipidaemic, antihypertensive, anthelmintic, antidiabetic and anticancer [26] The nutritional value of pumpkin seeds is due to the high protein content and the high energy potential of the high oil content. Oil in the seeds ranges $40 \%-60 \%$ of which $98 \%-99 \%$ is from the fatty acids oleic (up to $46.9 \%$ ), linolenic (up to $60.8 \%$ ), palmitic (up to $14.5 \%$ ), and stearic (up to $7.4 \%$ ). The ratio of monounsaturated to polyunsaturated fatty acids ranges from 0.60 to 0.75 [22]. [24]Pumpkin seeds and oil are rich in unsaturated fatty acids. Due to high omega-3 fatty acids [22] seeds and oil have been claimed to promote HIV/AIDS wellness [37] The lignans and phytosterolssuch as delta 7-sterols and delta 5-sterols, are of special interests [24] Moreover, antioxidative effects due to vitamin E, especially gammatocopherol were also considered. In fresh dried seeds concentration of alpha-tocopherol is $37.5 \mu \mathrm{g} / \mathrm{g}$ and gamma tocopherol is $383 \mu \mathrm{g} / \mathrm{g}$, [22]. Beneficial hypolipidaemic effects due to supplementation of either pumpkin seeds or oil have been shown in rats Also, mixing pumpkin seeds with flax or pursalne seeds caused decreases in lipid parameters and resulted in anti-atherogenic potential[6].Medicinal uses of husk tomato have been documented since early history; of these were antiasthmatic, anti-inflammatory, antispasmodic, anti-tumors and for urinary disorders [33]The effects of pumpkin seeds or oils combined with husk tomato on the health wellbeing of obese diabetic individuals still needs to be scrutinized. Therefore, it was the aim of the present study to investigate the effect of either or both plants on alleviating the adverse effects of diabetes in obese rats.

\section{Materials and Methods}

\subsection{Materials and Animals}

Casein, vitamins, minerals, cellulose, alloxan and choline chloride were purchased from El-Gomhoria Company, Cairo Egypt.Corn starch, saturated fat "beef tallow", soybean oil, pumpkin seeds were obtained from the Agriculture research center, Giza, Egypt and husk tomato were purchased from local market, Cairo, Egypt.

\section{Volume 6 Issue 1, January 2017




\section{International Journal of Science and Research (IJSR) \\ ISSN (Online): 2319-7064}

Index Copernicus Value (2015): 78.96 | Impact Factor (2015): 6.391

Male albino rats (Sprague Dawley Strain) were obtained from HelwanUniversity Experimental animal farm.

\subsection{Methods}

Chemical composition of dried pumpkin seeds and husk tomato

Moisture, Protein, fat, crude fiber and ash in pumpkin seeds and husk tomatowere determined according to the[4] while total carbohydrate was estimated mathematically by deference (Table 1).

Table 1: Chemical composition of Pumpkin seed and husk tomato fruits ( per $100 \mathrm{~g}$ )

\begin{tabular}{|c|c|c|}
\hline Nutrients & Pumpkin seed (\%) & Husk tomato (\%) \\
\hline Fat & 4.65 & 13.3 \\
\hline Protein & 17.35 & 11.5 \\
\hline Moisture & 11.76 & 3.2 \\
\hline Ash & 2.23 & 5.8 \\
\hline Carbohydrates & 64.01 & 66.2 \\
\hline
\end{tabular}

\begin{tabular}{|c|c|c|}
\hline Nutrients & Pumpkin see (\%) & Husk tomato (\%) \\
\hline Fat & 4.65 & 13.3 \\
\hline Protein & 17.35 & 11.5 \\
\hline Moisture & 11.76 & 3.2 \\
\hline Ash & 2.23 & 5.8 \\
\hline Carbohydrates & 64.01 & 66.2 \\
\hline
\end{tabular}

\subsection{Biological Experiment}

Forty eightmale albino rats with mean body weight of $160 \pm$ 10 gwere kept in individual stainless steel cages under hygienic conditions and fed on a basal diet adlibitum for adaptation period of one week according to [29]

After adaptation, rats were divided into two main groups. The first main group rats (control negative, $C-: n=6$ ) were fed on a basal diet.The basal diet for control composed of casein $(14 \%)$, corn oil $(4 \%)$, sucrose $(10 \%)$, vitamin mix $(1 \%)$, salt mix $(3.5 \%)$, cellulose $(5 \%)$ and corn starch $(62.5 \%)$. The second main group $(n=42)$ rats were fed for a period of 6 weeks on a high-fat diet (HFD) containing saturated fats(19\%), soybean oil $(1 \%)$ to provide essential fattyacids, sucrose $(10 \%)$, casein $(20 \%)$, cellulose $(5 \%)$, vitamin mixture (1\%), salt mixture $(3.5 \%)$, choline chloride $(0.25 \%)$ and the remainder was corn $\operatorname{starch}(40.25 \%)$ to induce obesity in rats [19]The second main group rats (obese group) were thereafter injected (i.m) with alloxan (120mg alloxan $/ \mathrm{kg}$ body weight) to induce diabetes according to the method described by Four days later, body weight gain was estimated in the first and second main groups and blood samples were collected from the eye of all rats to determine the levels of glucose, cholesterol and triglycerides as bioindicators of obesity. Thereafter, the second group rats were subdivided into seven subgroups; subgroup 1(control positive, $\mathrm{C}+$ ) animals fed on HFD, subgroup 2 (PS5) and 3(PS10) animals were fed on HFD containing 5 and $10 \%$ dried pumpkin seeds, respectively, subgroup 4 (HT5) and 5(HT10) animals were fed on HFD containing 5 and $10 \%$ husk tomato, respectively and subgroup 6 (PH3) and 7(PH6) animals were fed on HFD containing 3\% pumpkin seeds+ $3 \%$ husk tomato and $6 \%$ pumpkin seeds $+6 \%$ husk tomato, respectively. Therefore 8 groups of 6 rats each were designed and treatment lasted for 42 days. During the experimental period ( 6 weeks), the diets consumed and body weights were recorded per a week. At the end of the experiment, the rats were deprived of food overnight, anaesthetized and sacrificed, and blood samples were collected from the aorta. The blood samples were centrifuged and sera were separated and harvested to determine biochemicalparameters.Biochemical Attributes and Leptin Determinations Serum cholesterol was determined according to [2] triglycerids according to[13], high density lipoprotein HDL according to[17], low density lipoprotein LDL and VLDL according to [14] glucose according to [34], uric acid according to[12] urea nitrogen according to [27] creatinine aspartate amine transaminase (AST) and alanine amine transaminase (ALT) according to [30]alkaline phosphatase (ALP) according to [8] and the leptin according to [15]

\subsection{Relative Organs Weights}

Liver and kidneys were separated from each rat and weighed to calculate the relative liver and kidneys to body weight $(\%)$.

\subsection{Statistical Analysis}

Data were statistically analyzed by least square analysis of variances to compare the differences among groups (mean \pm standard deviation and one way ANOVA test) using SAS package[31] Differences between groups were estimated using Duncan's Multiple Range Test.The significant differences was considered at $\mathrm{P}<0.05$.

\section{Results and Discussion}

As shown in Table 2, at the conclusion of the study the increase in body weight in the obese-diabetic control positive rate approached $61 \%$ over the normal control animals.Supplementing animals with pumpkin or husk tomato maintained the high body weight. Relative liver weight tended $(\mathrm{P}>0.05)$ to increase in obese-diabetic rats, keeping that rats given PH6 (6\% Pumpkin seeds $+6 \%$ Husk tomato) showed the nearest liver relative weight similar to C- rats. Similar finding was found with relative kidneys weight revealing that PH6 rats had similar values to the control negative rats.

Table 2: Effect of dried pumpkin seeds, husk tomato and their combination on feed intake, body weight gainand relative kidneys and liver weights of obese-diabetic rats

\begin{tabular}{|c|c|c|c|c|}
\hline \multirow[t]{2}{*}{$\begin{array}{l}\text { Parameter } \\
\text { Group }\end{array}$} & \multirow{2}{*}{$\begin{array}{c}\text { Feed } \\
\text { intake } \\
\text { (g/day/ } \\
\text { rat) }\end{array}$} & \multirow[t]{2}{*}{$\begin{array}{l}\text { Body weight } \\
\text { gain } \%\end{array}$} & \multicolumn{2}{|c|}{$\begin{array}{c}\text { Organ weight/body } \\
\text { weight }(\%)\end{array}$} \\
\hline & & & Liver & Kidney \\
\hline Control (-) & 18.85 & $23.68^{\mathbf{c}} \pm 1.17$ & $2.58 \pm 0.91$ & $0.44^{\mathrm{d}} \pm 0.52$ \\
\hline Control (+) & 19.18 & $37.32^{\mathrm{a}} \pm 1.81$ & $3.42 \pm 0.15$ & $1.01^{\mathrm{a}} \pm 0.15$ \\
\hline $\begin{array}{l}\text { Dried pumpkin } \\
\text { seeds } 5 \% \text { (PS5) }\end{array}$ & 16.20 & $38.03^{\mathrm{a}} \pm 1.24$ & $3.03 \pm 0.44$ & $1.50^{\mathrm{a}} \pm 0.04$ \\
\hline $\begin{array}{l}\text { Dried pumpkin } \\
\text { seeds } 10 \% \\
\text { (PS10) }\end{array}$ & 15.53 & $28.67^{\mathbf{b}} \pm 1.96$ & $3.24 \pm 0.93$ & $0.98^{\mathbf{c}} \pm 0.54$ \\
\hline $\begin{array}{c}\text { Husk tomato } \\
5 \%(\mathrm{HT} 5)\end{array}$ & 16.40 & $30.28^{\mathbf{b}} \pm 1.19$ & $3.58 \pm 0.92$ & $0.87^{\mathfrak{c}} \pm 0.97$ \\
\hline Husk tomato & 18.80 & $32.38^{\mathbf{b}} \pm 1.74$ & $2.74 \pm 0.84$ & $0.67^{\mathbf{c}} \pm 0.52$ \\
\hline
\end{tabular}

\section{Volume 6 Issue 1, January 2017}




\section{International Journal of Science and Research (IJSR) ISSN (Online): 2319-7064}

Index Copernicus Value (2015): 78.96 | Impact Factor (2015): 6.391

\begin{tabular}{|c|l|l|l|l|}
\hline $10 \%$ (HT10) & & & & \\
\hline $3 \%$ Pumpkin & 16.54 & $33.86^{\mathbf{b}} \pm 1.74$ & $3.46 \pm 0.57$ & $1.21^{\mathbf{b}} \pm 0.10$ \\
seeds $+3 \%$ \\
$\begin{array}{c}\text { Husk tomato } \\
\text { (PH3) }\end{array}$ & & & & \\
\hline $\begin{array}{c}6 \% \text { Pumpkin } \\
\text { seeds + 6\% }\end{array}$ & 15.29 & $30.32^{b^{\prime}} \pm 1.42$ & $2.85 \pm 0.46$ & $0.53^{\mathrm{d}} \pm 0.44$ \\
$\begin{array}{c}\text { Husk tomato } \\
\text { (PH6) }\end{array}$ & & & & \\
\hline
\end{tabular}

*Mean \pm SD; Means in the same column with different

superscript letter are significantly different $(\mathrm{P}<0.05)$.

\section{Effects on lipids profiles}

Table 3 exhibits data of lipid fractions as affected by the treatment revealing a two folds cholesterol increase due to diabetes in obese rats, however various degrees of reductions accompanied treatments. The best treatment resulting the largest decrease in blood cholesterol was HT10 and PH6. Similar trend was found in triglycerides. HDL increased $(\mathrm{P}<0.05)$ by 4-7 folds by treatments. Likewise, about 6.5 folds increase in LDL was found in obese-diabetic rats than normal control, however significant $(\mathrm{P}<0.05)$ decreases were observed in rats given treatments, with HT10, PH6 and PS10 resulting the least concentration of LDL, even though the levels still above normal control by 3.5 folds. VLDL concentration elevates in positive control rats by about $50 \%$ of the normal control value, whereas PH6 was the sole treatment that restored the LDL to its normal value. Similar findings were concluded in diabetic-rats given pumpkin powder [5]The decrease in lipid fractions depends on the percent of pumpkin in the diet. Pumpkin contains various biologically active components, such as polysaccharides, para-aminobenzoic acid, fixed oils, sterols, proteins, peptides, carotenoids, $\gamma$-amino butyric acid and vitamins [13][10][22].Additionally, tomatillo was as effective as pumpkin in reducing blood lipids [28]

\section{Effects on kidney function}

As illustrated in Table 4, uric acid, urea nitrogen and creatinine were elevated in obese-diabetic rats by 2-3 folds above control rats. All treatments relatively reduced these figures with the best close to normal treatment of husk tomato $10 \%$ (HT10) and $6 \%$ pumpkin $+6 \%$ husk tomato (PH6) [3] found similar results of the improved renal function of obese rats by supplementing orlistat or pumpkin powder.The mechanism by which the pumpkin and tomatillo works might be ascribed to their contents of tetra cyclic triterpens, saponins, proteins, fibers, polysaccharides and minerals[10] and pectin [11]which alleviatethe toxic effects of alloxan on renal tubules.

\section{Effects on hepatic enzymes}

Table 5 exhibits data of the effects of pumpkin, tomatillo or their various mixtures on restoring the integrity of the liver in obese-diabetic rats. The induction of diabetes in alloxanintoxicated rats resulted in 2-5 folds increase in serum hepatic enzyme activities. The high levels of either herb or their combination at a high level (PH6) were the most effective to reduce the leakage of hepatic cellular enzymes, even though none of the treatments reduced the high values to its original level in negative control rats. [25] reported a hepato-protective effect inacetaminophen -intoxicated Sprague-Dawley rat's liver damage resulting in increases of serum AST and ALT. They found significant reductions in serum AST and ALT due to supplementing animal's diet with pumpkin seeds, attributing this effect to the protein content in seeds having potent antioxidants effect as revealed by chelating effect, antixanthine oxidaseproperties, and free radical scavenging activity. Also, different forms of tocopherol were isolated of pumpkin seeds showing enhancement for the $\beta$ cells in pancreas for insulin sensitivity [9]

Table 3: Effect of dried pumpkin seeds, husk tomato and their combination on lipid profile $(\mathrm{mg} / \mathrm{dL})$ of obese-diabetic

\begin{tabular}{|c|c|c|c|c|c|}
\hline $\begin{array}{l}\text { Pakameters } \\
\text { Groups }\end{array}$ & Cholesterol & $T G$ & $H D L$ & $L D L$ & $V L D L$ \\
\hline Control (-) & $\begin{array}{c}78.73^{\mathbf{e}_{ \pm}} \\
3.24^{*}\end{array}$ & $\begin{array}{c}41.42 \\
d_{ \pm} \pm 2.47\end{array}$ & $\begin{array}{c}4.84 \\
\mathbf{d}_{ \pm 1.98}\end{array}$ & $\begin{array}{l}21.30 \\
\mathbf{e}_{ \pm} \pm 1.88\end{array}$ & $\begin{array}{c}9.68^{\mathrm{e}_{ \pm}} \\
0.97\end{array}$ \\
\hline Control (+) & $\begin{array}{c}170.58^{\mathrm{a}} \pm \\
5.82\end{array}$ & \begin{tabular}{|c|}
79.89 \\
$a_{ \pm} \pm 3.52$
\end{tabular} & \begin{tabular}{|c|}
19.68 \\
$\mathbf{c}_{ \pm 1.89}$
\end{tabular} & $\begin{array}{l}140.27 \\
a_{ \pm 6.23}\end{array}$ & $\begin{array}{c}14.53 \\
\mathrm{a}_{ \pm} \pm 0.14\end{array}$ \\
\hline & $\begin{array}{r}160.0 \\
7.4\end{array}$ & $\begin{array}{c}57.98 \\
\mathbf{b}_{ \pm 4}\end{array}$ & \begin{tabular}{|c|}
27.15 \\
$\mathbf{b}_{ \pm 1.60}$
\end{tabular} & $\begin{array}{l}114.45 \\
\mathbf{b}_{ \pm 5.20}\end{array}$ & $\begin{array}{c}12.77 \\
\mathbf{b}_{ \pm 0.13}\end{array}$ \\
\hline $\begin{array}{r}\text { Dried pur } \\
\text { seeds } 1 \\
\text { (PS10 }\end{array}$ & $\begin{array}{c}132.19^{\mathbf{c}_{ \pm}} \\
4.02\end{array}$ & \begin{tabular}{|c|}
52.87 \\
$\mathbf{c}_{ \pm} 2.87$
\end{tabular} & $\begin{array}{c}34.69 \\
\mathbf{a}_{ \pm 2.10}\end{array}$ & $\begin{array}{c}77.00 \\
\mathbf{d}_{ \pm 1.19}\end{array}$ & $\begin{array}{c}11.19^{\mathbf{c}_{ \pm}} \\
0.58\end{array}$ \\
\hline $\begin{array}{c}\text { Husk Tomato } \\
5 \% \text { (HT5) }\end{array}$ & $\begin{array}{c}134.79^{c^{c}} \\
7.59\end{array}$ & $\begin{array}{c}56.19 \\
\mathbf{b}_{ \pm} \pm 4.01\end{array}$ & $\begin{array}{c}28.05 \\
\mathbf{b}_{ \pm} \pm 1.15\end{array}$ & $\begin{array}{l}104.30 \\
\mathbf{c}_{ \pm 6.98}\end{array}$ & $\begin{array}{c}12.13 \\
\mathbf{b}_{ \pm 0.01}\end{array}$ \\
\hline $\begin{array}{c}\text { Husk Tomato } \\
10 \%(\mathrm{HT} 10)\end{array}$ & $\begin{array}{c}118.70^{\mathrm{d}} \pm 4 . \\
45\end{array}$ & \begin{tabular}{|c|}
48.16 \\
$\mathbf{c}_{ \pm} 1.79$ \\
\end{tabular} & \begin{tabular}{|c|}
32.87 \\
$\mathbf{a}_{ \pm 2.89}$ \\
\end{tabular} & $\begin{array}{c}73.30 \\
\mathbf{d}_{ \pm 1.92}\end{array}$ & $\begin{array}{c}10.42 \\
\mathbf{c}_{ \pm 0.57}\end{array}$ \\
\hline $\begin{array}{c}\text { 3\% Pumpkin } \\
\text { Seeds }+3 \% \\
\text { Husk Tomato } \\
\text { (PH3) }\end{array}$ & $\begin{array}{c}137.71^{\mathbf{c}_{ \pm}} \\
8.14\end{array}$ & $\begin{array}{c}58.02 \\
\mathbf{b}_{ \pm} \pm 3.02\end{array}$ & $\begin{array}{r}29.36 \\
\mathbf{b}_{ \pm 1.23}\end{array}$ & $\begin{array}{c}107.45 \\
\mathbf{b c}_{ \pm 7.54}\end{array}$ & $\begin{array}{c}11.10 \\
\mathbf{b}_{ \pm 0.40}\end{array}$ \\
\hline $\begin{array}{l}\text { 6\% Pumpkin } \\
\text { Seeds }+6 \% \\
\text { Husk Tomato } \\
\text { (PH6) }\end{array}$ & $\begin{array}{c}123.44^{\mathrm{d}_{ \pm}} \\
3.84\end{array}$ & $\begin{array}{l}46.56 \\
\mathbf{c}_{ \pm 2.34}\end{array}$ & $\begin{array}{r}33.69 \\
a_{ \pm} \pm 1.42\end{array}$ & $\begin{array}{c}75.84 \\
\mathbf{d}_{ \pm 2.30}\end{array}$ & $\begin{array}{c}8.81^{\mathrm{d}} \pm 0 \\
.47\end{array}$ \\
\hline
\end{tabular}

$*$ Mean \pm SD

Means in the same column with different superscript letter are significantly different $(\mathrm{P}<0.05)$. HDL $=$ High density lipoprotein; LDL=Low density lipoprotein; VLDL=Very low density lipoprotein; $\mathrm{TG}=$ triglycerides .

Table 4: Effect of dried pumpkin seeds, husk tomato and their combination on kidney functions of obese-diabetic rats

\begin{tabular}{|c|c|c|c|}
\hline $\begin{array}{l}\text { Parameter } \\
\text { Group }\end{array}$ & $\begin{array}{l}\text { Uric acid } \\
(\mathrm{mg} / \mathrm{dL})\end{array}$ & $\begin{array}{c}\text { Urea nitrogen } \\
(\mathrm{mg} / \mathrm{dL})\end{array}$ & $\begin{array}{l}\text { Creatinine } \\
(\mathrm{mg} / \mathrm{dL})\end{array}$ \\
\hline Control (-) & $1.73^{\mathbf{f}} \pm 0.07$ & $24.35^{d} \pm 1.88$ & $0.57^{e} \pm 0.03$ \\
\hline Control (+) & $3.37^{\mathrm{a}} \pm 0.15$ & $73.35^{\mathrm{a}} \pm 3.92$ & $1.89^{\mathrm{a}} \pm 0.37$ \\
\hline $\begin{array}{l}\text { Dried pumpkin } \\
\text { Seeds 5\%(PS5) } \\
\end{array}$ & $2.68^{b} \pm 0.13$ & $55.26^{b} \pm 2.67$ & $1.44^{b} \pm 0.42$ \\
\hline $\begin{array}{c}\text { Dried pumpkin } \\
\text { seeds } 10 \%(\mathrm{PS} 10)\end{array}$ & $2.19^{d} \pm 0.39$ & $40.34^{\mathbf{c}} \pm 3.21$ & $0.91^{d} \pm 0.98$ \\
\hline $\begin{array}{c}\text { Husk tomato } \\
5 \%(\mathrm{HT} 5)\end{array}$ & $2.59^{\mathbf{c}} \pm 0.99$ & $51.31^{b} \pm 2.84$ & $1.81^{\mathbf{c}} \pm 0.05$ \\
\hline $\begin{array}{c}\text { Husk tomato } \\
10 \%(\mathrm{HT} 10)\end{array}$ & $1.97^{e} \pm 0.04$ & $36.82^{c} \pm 3.90$ & $0.85^{d} \pm 0.62$ \\
\hline $\begin{array}{c}\text { 3\% Pumpkin } \\
\text { Seeds }+3 \% \text { Husk } \\
\text { tomato(PH3) }\end{array}$ & $2.58^{\mathbf{c}} \pm 0.17$ & $52.80^{b} \pm 3.21$ & $1.39^{\mathbf{b}} \mathbf{c}_{ \pm 0.06}$ \\
\hline $\begin{array}{c}6 \% \text { Pumpkin } \\
\text { Seeds }+6 \% \text { Husk } \\
\text { tomato(PH6) }\end{array}$ & $2.06^{\mathrm{d}} \mathrm{e}_{ \pm 0.27}$ & $38.76^{\mathbf{c}} \pm 2.91$ & $0.91^{d} \pm 0.43$ \\
\hline
\end{tabular}

*Mean \pm SD; Means in the same column with different superscript letter are significantly different $(\mathrm{P}<0.05)$.

\section{Volume 6 Issue 1, January 2017 www.ijsr.net}




\section{International Journal of Science and Research (IJSR) \\ ISSN (Online): 2319-7064}

Index Copernicus Value (2015): 78.96 | Impact Factor (2015): 6.391

Table 5: Effect of dried pumpkin seeds, husk tomato and their combination on liverenzymes of obese-diabetic rats

\begin{tabular}{|c|c|c|c|}
\hline $\begin{array}{c}\text { Parameter } \\
\text { Group }\end{array}$ & $\begin{array}{c}\text { AST } \\
(\mathrm{U} / \mathrm{L})\end{array}$ & $\begin{array}{c}\text { ALT } \\
(\mathrm{U} / \mathrm{L})\end{array}$ & $\begin{array}{c}\text { ALP } \\
(\mathrm{U} / \mathrm{L})\end{array}$ \\
\hline Control (-) & $54.16^{\mathbf{e}} \pm 2.73$ & $17.49^{\mathbf{d}} \pm 2.02$ & $79.72^{\mathbf{d}} \pm 3.19$ \\
\hline Control (+) & $153.68^{\mathbf{a}} \pm 6.37$ & $78.59^{\mathbf{a}} \pm 3.48$ & $185.78^{\mathbf{a}} \pm 6.58$ \\
\hline $\begin{array}{c}\text { Dried Pumpkin } \\
\text { Seeds 5\% (PS5) }\end{array}$ & $143.50^{\mathbf{b}} \pm 3.20$ & $64.51^{\mathbf{b}} \pm 3.38$ & $162.89^{\mathbf{b}} \pm 6.20$ \\
\hline $\begin{array}{c}\text { Dried pumpkin } \\
\text { seeds 10\% (PS10) }\end{array}$ & $83.08^{\mathbf{d}} \pm 5.49$ & $42.88^{\mathbf{c}} \pm 3.32$ & $139.35^{\mathbf{c}} \pm 5.91$ \\
\hline $\begin{array}{c}\text { Husk Tomato 5\% } \\
\text { (HT5) }\end{array}$ & $136.64^{\mathbf{c}} \pm 3.37$ & $55.49^{\mathbf{b}} \pm 3.18$ & $165.65^{\mathbf{b}} \pm 4.16$ \\
\hline $\begin{array}{c}\text { Husk Tomato } \\
10 \% \text { (HT10) }\end{array}$ & $90.45^{\mathbf{d}} \pm 5.13$ & $42.98^{\mathbf{c}} \pm 2.49$ & $131.42^{\mathbf{c}} \pm 4.18$ \\
\hline $\begin{array}{c}3 \% \text { Pumpkin } \\
\text { Seeds + 3\% Husk } \\
\text { Tomato (PH3) }\end{array}$ & $129.77^{\mathbf{c}} \pm 3.25$ & $51.07^{\mathbf{b}} \pm 2.25$ & $168.12^{\mathbf{b}} \pm 6.90$ \\
\hline $\begin{array}{c}\text { 6\% Pumpkin } \\
\text { Seeds + 6\% Husk } \\
\text { Tomato (PH6) }\end{array}$ & $84.792^{\mathbf{d}} \pm 5.71$ & $48.81^{\mathbf{c}_{ \pm} \pm 2.47}$ & $139.43^{\mathbf{c}} \pm 5.40$ \\
\hline
\end{tabular}

$*$ Mean \pm SD; Means in the same column with different superscript letter are significantly different $(\mathrm{P}<0.05)$.AST $=$ Aspartate amine transaminase; $\mathrm{ALT}=$ Alanine amine transaminase; $\mathrm{ALP}=$ Alkaline phosphatase.

\section{Effects on serum glucose and leptin}

As shown in Table 6, serum glucose doubled in obesediabetic rats. However, supplementing these diabetic rats with tomatillo and/or pumpkin reduced $(\mathrm{P}<0.05)$ serum glucose to levels above normal control. The best treatments that resulted in the least amounts of glucose were PS10, HT10 and PH6, even though the reduction doesn't approach the normal level. Due to its insulin-production properties, the decrease in systemic glucose was evident. Evidently, as the level of either herbs increases it reduces the serum glucose, therefore it is anticipated that the increase above 105 might enhance the glucose level to reach its counterpart in negative control animals. It has been shown that the bioactive component in pumpkin is a polysaccharide [36] It has been demonstrated that polysaccharides content in a water extract pumpkin produces higher hypoglycemic effects than those of the glibenclamide in alloxan-induced diabetic rats [36][5] obtained lower glucose when diabeticrats were supplemented with pumpkin.Leptin increased in obese-diabetic rats by about 6 folds than negative control rats, however all treatments didn't restore its normal level $(2.31 \mathrm{ng} / \mathrm{ml})$. Since these rats were exposed to fattening, there appears that leptin which is mainly conserved in the adipose tissues was under which is defined as "leptin resistance" [23].

There are several mechanisms that regulate leptin actions and its resistance in the case of obesity especially on the hypothalamus [7]; [32]

In conclusion, administration of husk tomato and/or pumpkin seeds for the obese-diabetic rats at the levels of $10 \%$ or above mitigated the adverse effects on metabolic attributes, but didn't affect the leptin hormone. Further studies are warranted to pursue effects of supplementing higher levels of both herbs.
Table 6: Effect of dried pumpkin seeds, husk tomato and their combination on serum glucose and leptin of obesediabetic rats

\begin{tabular}{|c|c|c|}
\hline $\begin{array}{c}\text { Parameter } \\
\text { Group } \\
\end{array}$ & $\begin{array}{c}\text { Glucose } \\
\mathrm{mg} / \mathrm{dl}\end{array}$ & $\begin{array}{l}\text { Leptin } \\
\mathrm{ng} / \mathrm{ml}\end{array}$ \\
\hline Control (-) & $75.58^{f} \pm 3.48^{*}$ & $2.31^{\mathrm{d}} \pm 0.17$ \\
\hline Control (+) & $152.53^{\mathrm{a}} \pm 3.96$ & $15.43^{\mathrm{a}} \pm 1.34$ \\
\hline $\begin{array}{l}\text { Dried Pumpkin Seeds 5\% } \\
\text { (PS5) }\end{array}$ & $135.65^{\mathbf{b}} \pm 3.35$ & $15.50^{\mathrm{a}} \pm 1.89$ \\
\hline $\begin{array}{l}\text { Dried pumpkin seeds } 10 \% \\
\text { (PS10) }\end{array}$ & $98.43^{d^{d}} \pm 5.85$ & $13.96^{\mathbf{b}} \pm 0.68$ \\
\hline Husk Tomato 5\% (HT5) & $127.12^{\mathbf{c}_{ \pm}}$ & $12.80^{b} \pm 1.69$ \\
\hline Husk Tomato $10 \%$ (HT10) & $95.26^{\mathbf{e}_{ \pm}} 3.47$ & $10.36^{\mathbf{c}} \pm 0.89$ \\
\hline $\begin{array}{l}3 \% \text { Pumpkin Seeds }+3 \% \\
\text { Husk Tomato }(\mathrm{PH} 3)\end{array}$ & $129.92^{\mathbf{b} \mathbf{c}_{ \pm}}+3.51$ & $12.16^{\mathrm{b}} \pm 1.45$ \\
\hline $\begin{array}{c}6 \% \text { Pumpkin Seeds }+6 \% \\
\text { Husk Tomato (PH6) }\end{array}$ & $98.45^{\mathrm{d}} \pm 4.07$ & $.78^{c} \pm 1.64$ \\
\hline
\end{tabular}

*Mean \pm SD; Means in the same column with different superscript letter are

Significantly different $(\mathrm{P}<0.05)$.

\section{Acknowledgements}

The author would like to thank Prof. Dr. Ibrahim Said Salem, Prof. of Nutrition, Department of Nutrition and Food Science, Faculty of Home Economics, Helwan University, Egypt, for his great help and continuous encouragement throughout the work.

\section{References}

[1] Abdel-Barry, J.A.; Abdel-Hassan, I.A. and Al-Hakiem, M.H. (1997). Hypoglycaemic and antihyperglycaemic effects of Trigonella foenum-graecum leaf in normal and alloxan induced diabetic rats. J. Ethnopharmacol; 58: 149-55.

[2] Allain, C.; Poon, L. and Chan, C. (1974): Enzymatic determination of total serum cholesterol. Clin. Chem., 20:470-475

[3] Amin, K.A.; Galaly, S.R.;Hozayen, W.G.and Ramadan, S.M. (2014). Effects of Orlistat and Herbal Mixture Extract on Renal Function and Oxidative Stress Biomarkers in a Rat Model of High Fat Diet. International Journal of Biochemistry Research\& Review 4(2): 173-192.

[4] A.O.A.C. (1990). Official Methods of Analysis of Association of Official Agriculture Chemists, Washington, D.C.

[5] Asgary S., Moshtaghian S. J., Setorki M., Kazemi S., Rafieian-kopaei M., Adelnia A. and [Shamsi F. (2011). Hypoglycaemic and hypolipidemic effects of pumpkin (CucurbitapepoL.) on alloxan-induced diabetic rats. African Journal of Pharmacy and Pharmacology 5(23): 2620-2626

[6] Barakat LA, Mahmoud RH (2011). The antiatherogenic, renal protective and immunomodulatory effects of purslane, pumpkin and flax seeds on hypercholesterolemic rats. North Am J Med Sci 3:411417.

[7] Baskin DG, Schwartz MW, Seeley RJ, Woods SC, Porte D Jr, (1999). Leptin receptor long-form splicevariant protein expression in neuron cell bodies of the brain and co-localization with neuropeptide Y mRNA in 


\section{International Journal of Science and Research (IJSR) \\ ISSN (Online): 2319-7064}

Index Copernicus Value (2015): 78.96 | Impact Factor (2015): 6.391

the arcuate nucleus. J. Histochem. Cytochem. 47:353362.

[8] Belfield[8]Belfield. and Goldberg, D. M. (1971). Normal Ranges and Diagnostic Value of Serum 5'Nucleotidase and Alkaline Phosphatase Activities in Infancy. Arch Dis Child ; 46:842-846.

[9] Bharti SK, Kumar A, Sharma NK, Prakash BO, Jaiswal SK, (2013). Tocopherol from seeds of Cucurbita pepo against diabetes: Validation by in vivo experiments supported by computational docking. J. Formosan Med. Assoc. 112: 676-690.

[10]Bombardelli E, Morazzoni P (1997).CurcubitapepoL. Fitoterapia, 68 (4): 291

[11]Fissore EN, Matkovic L, Wider E, Rojas AM, Gerschenson LN (2009). Rheological properties of pectin-enriched products isolated from butternut (CucurbitamoschataDuch ex Poiret). LWT - Food Sci. Tech., 42: 1413-1421.

[12] Fossati, P.; Principe, L. and Berti, G. (1980). Enzymatic colorimetric method of determination of uric acid in serum. Clin Chem., 26(2): 227-273.

[13]Foster, L. B. and Dumns, T. T. (1973): Determination of triglycerides. J. Clin. Chem., 19:338-353.

[14] Friedwald, W.T.; Levey, R.I. and Fredrickson, D.S. (1972). Estimation of concentration of low-density lipoprotein separated by three different method. Clin. Chem., 18:499-502.

[15] Guillaume, M. and Bjorntorp, P. (1996): Obesity in Children, environmental and genetic aspects.Horm. Metab. Res. 28, 573-581.

[16]Khan, A. and Anderson, R.A. (2003). Insulin potentiating factor (IPF) present in foods, species and natural products. Pakistan Journal Nutrition; 2: 254-7.

[17] Lopes-Virella, M. F.; Stone, S.; Ellis, S. and Collwellm J. A. (1977): Cholesterol determination in high-density lipoproteins separated by three different methods. Clin. Chem., 23 (5): 882-893.

[18] Matus Z, Molna'r P, Szabo' LG (1993). Main carotenoids in pressed seeds (Cucurbitae semen) of oil pumpkin (Cucurbitapepoconvar. pepo var. styriaca) (article in Hungarian). Acta. Pharm. Hung., 63: 247256.

[19] Min, L.; Ling, S.; Yin, L.; Stephen, C.W.; Randy, J. S.; David, D. and Patrick, T. (2004):Obesity induced by a high-fat diet downregulatesapolipoprotein A-IV gene expression in rat hypothalamus. Am. J. Physiol. EndocrinolMetab. 287: E366-E370.

[20] Murković, M., A. Hillebrand, J. Winkler, E. Leitner, and W. Pfannhauser. (1996). Variability of fatty acid content in pumpkin seeds (CucurbitapepoL.). Eur. Food Res. Technol. 203:216-219.

[21] Murković, M., V. Piironen, A.M. Lampi, T. Kraushofer, and G. Sontag.(2004). Changes in chemical composition of pumpkin seeds during roasting process for production of pumpkin seed oil (Part 1: non-volatile compounds). Food Chem. 84:359-365.

[22] Murkovic M, Mulleder U, Neunteufl H (2002). Carotenoid content in different varieties of pumpkins. J. Food Comp. Anal., 15: 633-638.
[23] Myers, M.G.; Cowley, M. A.; and Heike Münzberg, H. (2008). Mechanisms of leptin action and leptin resistance. Ann. Rev. Physiol., 70:537-556.

[24] Nakić, S.N., D. Rade, D. Kevin, D. Štrucelj, Z. Mokrovčak, and M. Bartolić. (2006). Chemical characteristics of oils from naked and husk seeds of CucurbitapepoL. Eur. J. Lipid Sci. Technol. 108:936943.

[25] Nkosi CZ, Opoku AR, Terblanche SE (2006). In Vitro antioxidative activity of pumpkin seed (Cucurbitapepo) protein isolate and its in vivo effect on alanine transaminase and aspartate transaminase in acetaminophen- induced liver injury in low protein fed rats. Phytother. Res. 20: 935-940.

[26] Patel, S. (2013). Pumpkin (Cucurbita sp.) seeds as nutraceutic: a review on status quo and scopes. Mediterr. J. Nutr. Metab., 6: 183-189.

[27] Patton, C.J. and Crouch, S.R. (1977). Enzymatic colorimetric method to determination urea in serum. Anal. Chem.,49:464.

[28] Puente, L. A., C. A. Pinto-Munoz, E. S. Castro, and M. Cortes. (2011).Physalisperuviana L., the Multiple Properties of a Highly FunctionalFruit: a Review. Food Research International44:1733-1740.

[29] Reeves, P. G.; Nielsen, F. H. and Fahmy, G. C. (1993): AIN-93 purified diets for laboratory rodents: final report of the American Institute of Nutrition ad hoc writing committee on the reformulation of the AIN-76A rodent diet. J. Nutr.;123(11):1939-1951.

[30] Reitman, S. and Frankel, S. (1957):Determination of glutamate pyruvate transferase. Am. J. Clin. Path., 28:56.

[31] SAS, (1996): "Statistical Analysis System" SAS User's Guide: Statistics. SAS Institute Inc. Editors, Cary, NC.

[32] Schwartz MW, Woods SC, Porte D Jr, Seeley RJ, Baskin DG. (2000). Central nervous system control of food intake. Nature 404:661-671.

[33] Silva M, Simas S, Batista T, Cardarelli P, Tomassini T. (2005). Studies on antimicrobial activity, in vitro, of PhysalisangulataL. (Solanaceae) fraction and physalin $\mathrm{B}$ bringing out the importance of assay determination. MemInstOswaldo Cruz 100: 779 - 782.

[34] Trinder, P.(1959): Determination of blood glucose using 4-aminophenazone. J. Clin. Path., 22:246.

[35] Weiser, M.; Frishman, W.H.; Michaelson, M.D. and Abdeen, M.A. (1997). The pharmacologic approach to the treatment of obesity. J. clin. Pharmacol.; 37:453-73.

[36]Zhang YJ (2004). Study on the hypoglycemic effects and extraction and analysis of pumpkin polysaccharide. J China Jiliang University 15: 0238-0241.

[37]Zimmerman, J.R.D. (1997). Optimal nutrition for HIV/AIDS wellness. J. Am. Diet. Assoc. 97:Suppl. 1, A 18.

\section{Author Profile}

Shimaa Mohammed Aboelnaga has done Bachelor of Home Economic - nutrition \&food science department , Master degree in nutrition therapy and Ph.D. in nutrition therapy. She worked atthe University of Hail as assistant professor in study skills department Preparatory Year, Kingdom of Saudi Arabia . 
Volume 6 Issue 1, January 2017

www.ijsr.net

Licensed Under Creative Commons Attribution CC BY 